\title{
Different This Time? The Prospects of CCS in the Netherlands in the 2020s
}

\author{
Sanne Akerboom ${ }^{1 *}$, Svenja Waldmann ${ }^{1}$, Agneev Mukherjee ${ }^{1,2}$, Casper Agaton ${ }^{3}$, \\ Mark Sanders ${ }^{4}$ and Gert Jan Kramer ${ }^{1}$ \\ ${ }^{1}$ Copernicus Institute of Sustainable Development, Utrecht University, Utrecht, Netherlands, ${ }^{2}$ Organic Chemistry \\ and Catalysis, Debye Institute for Nanomaterials Science, Utrecht University, Utrecht, Netherlands, ${ }^{3}$ Utrecht School \\ of Economics, Utrecht University, Utrecht, Netherlands, ${ }^{4}$ School of Business and Economics, Maastricht University, \\ Maastricht, Netherlands
}

OPEN ACCESS

Edited by:

Carlos Pozo,

University of Girona, Spain

Reviewed by:

Andres Fernando Clarens, University of Virginia, United States

David S. Goldberg,

Columbia University, United States

*Correspondence: Sanne Akerboom

s.akerboom@uu.n

Specialty section:

This article was submitted to

Carbon Capture, Storage, and Utilization,

a section of the journal

Frontiers in Energy Research

Received: 21 December 2020

Accepted: 14 April 2021

Published: 04 May 2021

Citation:

Akerboom S, Waldmann S, Mukherjee A, Agaton C, Sanders M and Kramer GJ (2021) Different This

Time? The Prospects of CCS

in the Netherlands in the 2020s.

Front. Energy Res. 9:644796.

doi: 10.3389/fenrg.2021.644796
Carbon Capture and Sequestration (CCS) has been recognized as an important means of mitigating global climate change, but apart from several pilots, it has not yet been successfully implemented on the large scale needed to live up to the expectations as a mitigation method. In Netherlands, the option of CCS has been the subject of debate for a long time, as three unsuccessful projects - two onshore in Barendrecht and the Northern regions, and one offshore near the Port of Rotterdam - demonstrate. Nevertheless, CCS has been accorded an important place in the current Dutch climate policies, being expected to contribute up to 7 Megaton of $\mathrm{CO}_{2}$ reduction. This is reflected in a fresh crop of CCS project plans. For the most, these plans have a long way to go from the drawing board to actual operations due to the technical, economic, legal and societal challenges ahead. In this article we review the status and possibilities of CCS in Netherlands based on an analysis of existing literature in the relevant disciplines. First, a brief overview of the technology options for carbon capture and storage or utilization is given. This is followed by a detailed analysis of the governmental support for CCS, given the vital role that fit-for-purpose legal frameworks and policy instruments will play in CCS deployment. Technical, legal and policy uncertainties translates into factors inhibiting CCS investment and so the paper then presents a CCS investment project to illustrate how such risks affect the business case for CCS. Finally, bearing in mind that societal acceptance has proved to be a major barrier for CCS, both in Netherlands and elsewhere, the conditions that enhance public acceptance of CCS are examined. Our work shows that while CCS is technically a straightforward proposition, its deployment has historically been hindered by the lack of a sound business case and a compelling and stable socio-technical narrative. The main argument in favor of CCS today is that it offers a transition pathway for rapidly and massively reducing $\mathrm{CO}_{2}$ emissions beyond what could be accomplished by alternative methods like electrification and renewable fuels in near future. The introduction of new financial instruments, increased government support and an improvement in social engagement appear to have enhanced the prospects of CCS in Netherlands, but we feel it is premature to assume that this time everything is different.

Keywords: carbon capture and storage (CCS), carbon capture and utilization (CCU), sustainability, uncertainties analysis, climate action plan $2030+$ 


\section{INTRODUCTION}

With the Paris Agreement of UNFCCC (2015), the community of nations has committed to the very ambitious global target of keeping temperature rise below $2^{\circ} \mathrm{C}$, and preferably to $1.5^{\circ} \mathrm{C}$. This target can only be reached when national greenhouse gas (GHG) emission reductions add up to the required global reduction. The current set of pledges (the so-called Nationally Determined Contributions) are far from the Paris goal (IPCC, 2018). A step change in national ambitions, along with credible plans for their implementation, is therefore needed.

In this spirit, in 2017 the newly elected government of Netherlands set an ambitious target for 2030, of reducing national $\mathrm{CO}_{2}$ emissions by $49 \%$ relative to 1990 . This requires 48.7 Megaton (Mt) of additional reductions compared to the baseline outcome of existing policies (PBL, 2019b). These targets have been laid down in a Klimaatwet (Climate Act) and the public-private Klimaatakkoord (Climate Agreement) negotiated in 2018-2019 sets out the pathway to sustainability (Klimaatakkoord, 2019; Klimaatwet, 2019).

Carbon Capture and Sequestration (CCS) is an important instrument in the Klimaatakkoord, providing proposed emissions reductions of up to $7.2 \mathrm{Mt}$ annually until 2030, second in importance only to the contribution of new renewables (see Figure 1).

In recognition of the magnitude of the challenge, mitigation measures are typically driven to their plausible maximum. The deployment of CCS, however, comes with multiple restrictions. On the one hand, CCS can make a large contribution to mitigation but, on the other hand, there is a reluctance to embrace the technology - that is: to cap supporting subsidies for its deployment before it has even begun. This wavering attitude has strongly influenced the case for CCS in Netherlands in earlier decades. This prompts the question in the title of this paper: Different this time?

Whilst this paper presents a case study of CCS in Netherlands, it will also shed light on the challenges facing CCS deployment globally. Netherlands, with its ample on- and offshore storage capacity in depleted natural gas fields, its well developed infrastructure and excellent knowledge base and well-functioning institutional framework, is globally perhaps best positioned to pioneer this technology. One might say that if CCS does not succeed in Netherlands or in Norway, it is hard to imagine where it would have a better chance. This is concerning, the successful global rollout of CCS on a massive, gigaton per annum-scale, is essential to meet the global climate target and limit global warming to $2^{\circ} \mathrm{C}$ or below. As evidence of this, three of the four scenarios in the IPCC's $1.5^{\circ} \mathrm{C}$ report from 2019 include CCS (IPCC, 2018).

To examine whether CCS deployment in Netherlands can be successful, we distinguish between three important stakeholders:

Abbreviations: CCS, carbon capture and storage; CCU, carbon capture and utilization; CCUS, carbon capture utilization and sequestration; CFPP, coalfired power plants; EII, energy intensive industry; EU, European Union; ETS, emission trading system; PBL, environmental planning agency; GHG, greenhouse gas emissions; Mt, megaton; OM, operations and maintenance; ODE, opslag duurzame energie; SDE +++ , stimulating sustainable energy. government, business (industry) and society. As we will show below, society has been an important factor in blocking onshore CCS projects (Brunsting et al., 2011; Kuijper, 2011; Terwel and Daamen, 2012; van Os et al., 2014; van Egmond and Hekkert, 2015). From the ROAD project we have learned that businesses will not invest in CCS unless there is a viable business case (Read et al., 2019), and subsidies are not enough by themselves to build a solid business case on alone. Generally, it has also been found that CCS projects slow down due to insufficient support from the government (Karimi, 2017). Therefore, we will highlight the role of each of these stakeholders towards successful implementation of CCS in Netherlands in the 2020s.

In the subsequent sections of this paper we look at the case for CCS from different perspectives: technological (Section "Technology Options: CCS, CCU, and CC(U)S"), governmental (Section "Governmental Support for CCS"), economic (Section "Investment Uncertainties of CCS"), and societal (Section "Societal Acceptance of CCS"). In the final section "Analysis Different This Time?" we draw some tentative conclusion about the fate of CCS in the coming decade and point out what we see as the most critical aspects. First, however, we start with a short history of CCS in Netherlands.

\section{A BRIEF HISTORY OF CCS IN NETHERLANDS AND EUROPE}

Netherlands is geographically and economically well positioned for CCS. The large natural gas reserves that have been exploited since the 1950s provide suitable storage capacity close at hand. The Dutch industry is both energy intensive and geographically concentrated in a few industrial districts, such that transport and capture can benefit from economies of scale, scope and agglomeration. This is similar to Norway, which has a long history of CCS pilots and demonstration projects. Despite all these advantages, to date no industrial scale CCS projects are operational to date.

In this section we recap the recent history of CCS in Netherlands by describing the course of events for the three Dutch CCS projects that were proposed, and in two cases abandoned or reshaped.

\section{The First Dutch CCS Project Plans (2000-2017)}

In recent history, Netherlands has attempted three CCS projects: two onshore in Barendrecht and the Northern regions and one offshore near the Rotterdam Port. None of the projects were realized because of a combination of societal, political and funding challenges.

The onshore CCS project in Barendrecht faced societal resistance. In 2008, Shell Global Solutions International B.V. won a government tender to store approximately $10 \mathrm{Mt} \mathrm{CO}_{2}$ over 25 years ( $0.4 \mathrm{Mt} /$ year) from Shell's refinery near Rotterdam in a subsurface natural gas reservoir close to the Barendrecht, a suburb of Rotterdam. The project was seen as being technically straightforward, and the main aim of Shell and the government at the outset was to test the legal and regulatory frameworks 
25

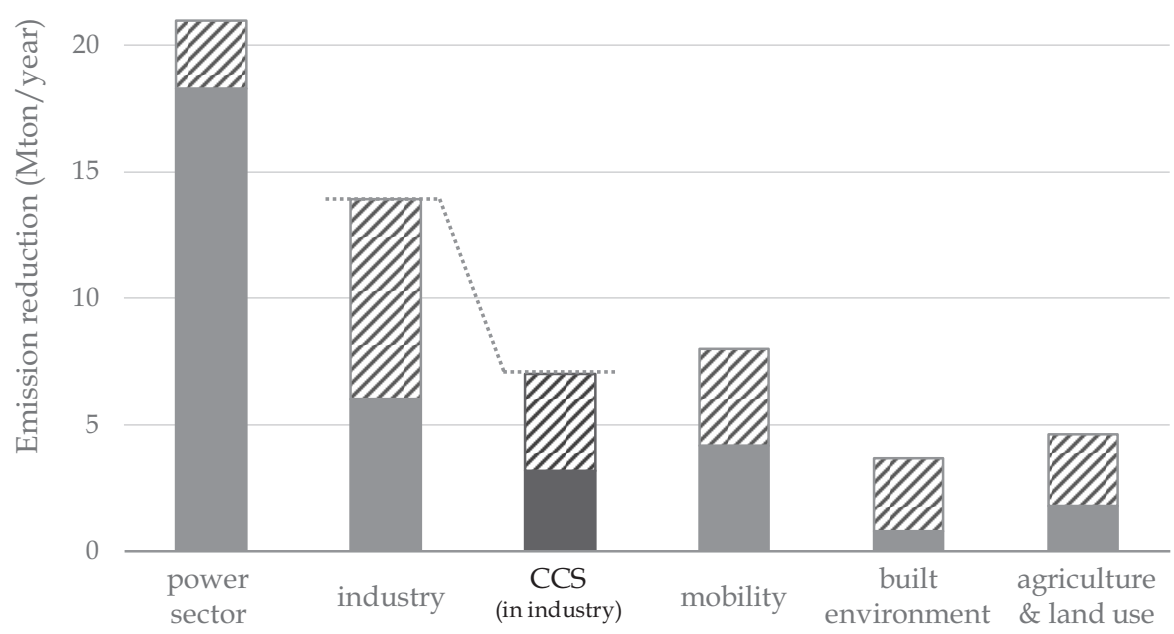

FIGURE 1 | Projected annual emission reductions in Netherlands in 2030, based on the Dutch 2019 Klimaatakkoord, according to analysis of the Dutch Environmental Planning Agency (PBL). The Klimaatakkoord allocates the emission reduction task to five sectors of the energy economy (gray). CCS is part of industry. The hashed areas indicate the uncertainty between low and high estimates for 2030 (PBL, 2019a).

for CCS, as well as the monitoring and verification procedures (Lockwood, 2017). The examination of possible local concerns, on the other hand, was not given sufficient consideration prior to the announcement of the project (Ashworth et al., 2012). Right after the selection of the project by the Minister of Economic Affairs and a first public hearing in Barendrecht, critical questions were raised about safety issues and negative impacts on human health and the environment. Horror stories of a $\mathrm{CO}_{2}$ blowout from the subsurface became part of the narrative in the media presence (Feenstra et al., 2010; Lockwood, 2017). Due to this increasingly negative perception of CCS by the broader public, the project was put on hold and additional studies were requested. At the same time earthquakes caused by the production of natural gas from subsurface reservoirs occurred close to Groningen. The rather technocratic and legalistic approach of the industrial stakeholders and policy makers allowed the situation to get out of hand. Emotions cannot be assuaged with facts and scientific studies, and political parties were not prepared to lose political capital and votes over the project. Around 2010, close to the general election of a new Parliament, political support fell away, resulting in the cancelation of the project (Brunsting et al., 2011; Kuijper, 2011; Terwel and Daamen, 2012; van Os et al., 2014; van Egmond and Hekkert, 2015).

Around the same time, another onshore CCS project Nothern Netherlands CCS initiative - was undertaken, although this project was canceled quickly after its presentation. Although this project also met with local opposition, van Os et al. (2014) found that this was not solely responsible for the abandonment of the project. No clear organizational division of tasks and responsibilities could be established, and the current legal and governance framework was found to provide insufficient to provide guidance. This was also mentioned as an important element for the failure of CCS project close to the port of Rotterdam (ROAD project) (Warmenhoven et al., 2018).

The failure of two onshore CCS projects shortly after each other made clear that making CCS a reality in a densely populated country like Netherlands is more than an engineering problem. As a consequence of these events, the focus of $\mathrm{CO}_{2}$ storage shifted away from onshore to offshore.

The third Dutch CCS launch project, the ROAD project, was conceived in the early 2010s, and was a joint attempt by E.ON Benelux and Electrabel Nederland (now Uniper Benelux and Engie Nederland, respectively) to demonstrate the technical and economic feasibility of large-scale and integrated CCS. It aimed at offshore storage of $1 \mathrm{Mt}$ of $\mathrm{CO}_{2}$ per annum, to be captured from the newly built coal-fired power plant (CFPP) Maasvlakte 3. In the ROAD project, $\mathrm{CO}_{2}$ would be transported via existing gas pipelines to two offshore (condensate) natural gas fields located in shallow water $20 \mathrm{~km}$ offshore in the North Sea, northwest of the CFPP. The storage capacity of both fields was estimated to be more than $10 \mathrm{Mt} \mathrm{CO}_{2}$. Since the project would repurpose an existing pipeline to a depleted gas field, the transport and storage part of the ROAD project was ready to go, while a 1.1 $\mathrm{Mt} /$ year facility for flue gas (post combustion) capture had been designed. In fact, the permission to build the Maasvlakte 3 power plant was conditional on it being capture-ready so that the plot space and tie-ins were available (Read et al., 2019). Although the Maasvlakte Power Plant 3 came online in 2015 (Lockwood, 2017), the CCS element of the project was mothballed in 2014 due to a lack of clarity on financing (Carbon Capture and Sequestration Technologies Program at MIT, 2016). Finally, Uniper and Engie decided to withdraw from the project in 2017 citing the lack of political support and a sustainable business case for coalfired power generation in combination with CCS, leading to the 
cancelation of the project (NLOG, 2017; Port of Rotterdam, 2017; Read et al., 2019).

\section{The Current Crop of Dutch and European CCS Projects}

In Europe, only two large-scale storage projects are operational; both of them in Norway. They are the Sleipner project in the norther North Sea, $250 \mathrm{~km}$ west of Stavanger and the Snøhvit project in the Barents Sea, north of Hammerfest. Between them, $1.7 \mathrm{Mt} \mathrm{CO}_{2}$ per year is stored. For both projects, the $\mathrm{CO}_{2}$ comes from natural gas production. Natural gas from the Sleipner field contains up to $9 \% \mathrm{CO}_{2}$, and that from the Snøhvit field 5-6\%. The $\mathrm{CO}_{2}$ is separated prior to the purified natural gas being injected in the gas grid (Sleipner) or liquefied (Snøhvit) (IEAGHG, 2016).

In Europe (United Kingdom, Norway, Ireland, and Netherlands) ten large-scale CCS facilities are currently on the drawing board and/or in different stages of development, intended to be operational in the 2020s. Facility industries related to these operations are of different nature, ranging from power generation and hydrogen production to natural gas processing and oil refining. When operational, these facilities combined will capture $20.8 \mathrm{Mt} \mathrm{CO}_{2}$ per year (Global CCS Institute, 2019).

The Porthos project in Netherlands is one of the most advanced European CCS projects under development. A joint project between the Port of Rotterdam Authority, Energie Beheer Nederland B.V. (EBN) and Nederlandse Gasunie N.V., Porthos envisages various companies supplying their $\mathrm{CO}_{2}$ to a collective pipeline running through the Rotterdam port area. It thus offers the possibility of combining $\mathrm{CO}_{2}$ capture from clusters of industrial installations with shared infrastructure in the Port of Rotterdam. The project initially aims at storing $2 \mathrm{Mt} \mathrm{CO}_{2}$ per year, with the possibility of increasing capacity to $5 \mathrm{Mt} \mathrm{CO}_{2}$ per year by 2030 (Gasunie, and EBN, 2018).The storage location is the same depleted offshore natural gas field previously targeted by the ROAD project. The final investment decision is expected in 2021, with $\mathrm{CO}_{2}$ storage under this project expected to start by end-2023 (Rotterdam CCUS, 2019).

Two other projects (Athos and Aramis) are currently under development in Netherlands. Like Porthos they combine $\mathrm{CO}_{2}$ capture with for the development of shared infrastructure and storage facilities. The Athos project - a consortium of EBN, Gasunie New Energy, Port of Amsterdam and Tata Steel IJmuiden - explores Carbon Capture Utilization and Sequestration (CCUS) opportunities in the Noordzeekanaal industrial cluster and has the ambition of storing up to $7.5 \mathrm{Mton} \mathrm{CO}_{2}$ per year in offshore subsurface reservoirs (IOGP, 2020). The Aramis project is being developed by a consortium of the Nederlandse Aardolie Maatschappij B.V., Total, and EBN for the port of Den Helder in the north of Netherlands. The project was launched mid-2019 and a feasibility study for offshore $\mathrm{CO}_{2}$ storage is now being conducted (IOGP, 2020). While the start date and capacity have yet to be decided, the existing infrastructure can potentially accommodate a $10 \mathrm{Mt} / \mathrm{y}$ project (van Bracht and Braun, 2018). Another project in the earlydevelopment stage is the Hydrogen 2 Magnum project. A joint venture between Equinor, Vattenfall and Gasunie, the project will involve the conversion of natural gas to hydrogen (blue hydrogen), which will be used in the Dutch gas-fired power plant Magnum in Eenshaven. The resultant carbon dioxide will be stored in the Norwegian Sleipner field (Equinor, 2020).

Among them, these projects now cover the larger industrial clusters with access to offshore natural gas reservoirs. If implemented, the storage capacity would exceed the agreed volumes of captured and stored $\mathrm{CO}_{2}$ as given in the Dutch Klimaatakkoord. However, the projects have a long way to go from the drawing board to actual operations. There are technical, then economic and finally legal and societal challenges ahead.

\section{TECHNOLOGY OPTIONS: CCS, CCU, AND CC(U)S}

\section{Overview of the CCS Technology Development}

Carbon capture and sequestration implementation faces several challenges on various fronts, such as social acceptance and buildup of a sound business case as earlier projects have shown in Netherlands. Technologically, however, in-depth knowledge of the different constituents of CCSare well in place, although further CCS processing is needed for site specific developments. Here, we provide a short overview of the technology status of CCS, before considering the prospects of a more recently proposed CCS alternative, Carbon Capture and Utilization (CCU), as well as its combination with storage (CCUS or $\mathrm{CC}(\mathrm{U}) \mathrm{S})$.

The first step in carrying out CCS is capturing $\mathrm{CO}_{2}$ from industrial plants, for which numerous technological alternatives exist. The choice of the respective capture technology depends on various factors such as the $\mathrm{CO}_{2}$ concentration in the capture gas stream, the pressure, the fuel type, and whether the plant is a retrofit or greenfield (i.e., fully new-built) development. In the context of $\mathrm{CO}_{2}$ capture from power plants, post-combustion capture is the most well-developed technology, which can be retrofitted to already existing plants (Leung et al., 2014). However, the main challenge for post-combustion capture is the high energy load that is needed to capture significant amounts of $\mathrm{CO}_{2}$ from the flue gas. The cause lies in the low concentration of $\mathrm{CO}_{2}$ in powerplant flue gas (4-14\%) (Olajire, 2010). This is exacerbated by the need to raise purity of the captured $\mathrm{CO}_{2}$ to $95 \%$ or higher for pipeline transport (de Visser et al., 2008). For other industrial plants, pre-combustion capture is the leading option. Here, $\mathrm{CO}_{2}$ is captured from the reformate stream by steam methane reforming, which is the main industrial process for hydrogen $\left(\mathrm{H}_{2}\right)$ production. The much higher $\mathrm{CO}_{2}$ concentration (15-60\%) facilitates the $\mathrm{CO}_{2}$ separation as compared to post-combustion capture (IPCC, 2005).

Two additional options must be mentioned, both less mature than the above capture technologies. The first is pre-combustion capture from solid fuels,such as coal or biomass. Here the fuels are first gasified using partial oxidation or steam reforming to a mixture of mainly carbon monoxide $(\mathrm{CO})$ and $\mathrm{H}_{2}$. With the addition of water vapor $\left(\mathrm{H}_{2} \mathrm{O}\right)$ the $\mathrm{CO}$ is converted into $\mathrm{CO}_{2}$ 
and additional $\mathrm{H}_{2}$, with the $\mathrm{CO}_{2}$ being captured (Olajire, 2010). The second option is oxyfuel combustion, a modified postcombustion capture method where pure oxygen is used instead of air as the combustion medium. This process significantly increases the $\mathrm{CO}_{2}$ concentration in the flue gas to $>80 \%$ by eliminating the nitrogen content (Olajire, 2010; Leung et al., 2014). The large quantity of pure oxygen required is the major disadvantage, raising both capital costs and energy penalty.

In addition to the capture technology, the separation technology also affects the costs and energy penalties. Physical and chemical absorption, adsorption, cryogenic distillation, membrane-based separation, hydrate-based separation have been researched, with their suitability depending partly on the capture technology used (IPCC, 2005; Olajire, 2010; Leung et al., 2014).

On the transport front, pipelines are the most cost-effective option for large-scale, long-distance $\mathrm{CO}_{2}$ transport. The $\mathrm{CO}_{2}$ is transported in supercritical state with gas pressure above 7.4 MPa and a temperature of $31.1^{\circ} \mathrm{C}$ (WorleyParsons, 2009). Fracture-tough steel is mandatory for the pipelines, and intermediate compressor stations may be needed to guarantee the required pressure and temperature (WorleyParsons, 2009). Overall, pipeline transport of $\mathrm{CO}_{2}$ is very similar to that of any other hazardous liquid or gas. In case the $\mathrm{CO}_{2}$ capture point does not have ready access to pipeline facilities, railroads or truck tankers may be used, while ship tankers similar to those used for liquefied natural/petroleum gas can be used for offshore transport (IPCC, 2005; WorleyParsons, 2009).

$\mathrm{CO}_{2}$ storage in geological formations is realized by injecting $\mathrm{CO}_{2}$ to depths greater than a few hundred meters, with low permeability caprock and other geological trapping mechanisms preventing the escape of the gas towards the overburden. The well-drilling and injection technology, computer simulation of the storage reservoir performance, and required monitoring methods are similar to those already in use in the oil and gas industry (IPCC, 2005).

\section{Development, Restrictions, and Opportunities for Large-Scale CCU}

From a techno-economic perspective, storage became challenged because of the seeming incongruity of expending large sums of capital to capture $\mathrm{CO}_{2}$ and then storing it underground, thereby foregoing to opportunity to re-use the carbon and 'close the loop'. This has given rise to the idea of carbon utilization. With CCU, the captured $\mathrm{CO}_{2}$ is used as a 'renewable' raw material instead of being treated as waste, potentially making $\mathrm{CO}_{2}$ capture economically desirable rather than merely an unprofitable addition to the project cost (Cuéllar-Franca and Azapagic, 2015). As a $\mathrm{CO}_{2}$ mitigation option, however, the potential of CCU depends on its definition. The use of $\mathrm{CO}_{2}$ as a chemical building block or building material can allow longterm removal of $\mathrm{CO}_{2}$ from the atmosphere, but such use is likely to account for under $10 \%$ of worldwide $\mathrm{CO}_{2}$ emissions (von der Assen et al., 2014; Chauvy et al., 2019). The synthesis of fuels like methane and methanol, on the other hand, can permit far larger scale $\mathrm{CCU}$ deployment at the cost of a shorter $\mathrm{CO}_{2}$ cycle. Some projections state that technology mixes incorporating
CCU fuels (electrofuels) can allow climate change targets to be met at far lower costs than full electrification scenarios (IOGP, 2019). This optimism needs to be balanced against the fact that CCU fuels are today far more expensive than their fossil fuel counterparts (Dimitriou et al., 2015; Pérez-Fortes and Tzimas, 2016; Cuéllar-Franca et al., 2019; Kraan et al., 2019). The chemical inertness of $\mathrm{CO}_{2}$ means that aids, either as direct energy supply or in the form of energy-rich co-reactants, are generally needed to convert it into useful products (Porteron et al., 2019). This alters the total energy balance and reduces the potential for GHG mitigation of CCU options. Indeed, an implicit assumption in CCU deployment is the availability of sufficient quantities of cost-effective renewable energy. While the substitution of energy-rich compounds with $\mathrm{CO}_{2}$ in a process chain can lead to increased energy efficiency, $\mathrm{CO}_{2}$ conversion into compounds such as hydrocarbons necessitates the use of renewable energy for this approach to be superior to conventional petrochemical technologies (Porteron et al., 2019). $\mathrm{CO}_{2}$ is already used as a raw material in certain industries, but only urea production can be considered to be a commercial-scale deployment of CCU (Fortunato, 2018).

In the near term, therefore, progress on $\mathrm{CCU}$ is expected to concentrate on matching large point sources of concentrated $\mathrm{CO}_{2}$ with large-scale consumers. While the power sector is the largest $\mathrm{CO}_{2}$ emitting group, the low concentration of $\mathrm{CO}_{2}$ in powerplant flue gas (4-14\%) requires the handling of a large volume of gas, increasing equipment size and costs (Olajire, 2010). Industries such as ammonia and hydrogen production, or steel production using the HIsarna process, produce large flue gas streams of almost pure $\mathrm{CO}_{2}$, and these may therefore be more suitable initially for CCU implementation.

In the Dutch context, the use of $\mathrm{CO}_{2}$ in horticulture (up to $2.1 \mathrm{MT} / \mathrm{y}$ by 2030) has been pitched as an enticing nearterm CCU option (Croezen et al., 2018). As the $\mathrm{CO}_{2}$ that is sequestered in plants is soon released back into the atmosphere, this is not considered as a $\mathrm{CO}_{2}$ reduction in $\mathrm{CO}_{2}$ accounting practices. However, the use of captured $\mathrm{CO}_{2}$ in horticulture can still lead to net avoided $\mathrm{CO}_{2}$ emissions of $300-950 \mathrm{~kg} \mathrm{CO} 2$ per ton of $\mathrm{CO}_{2}$ captured, because it will replace the current practice of burning natural gas to generate fresh $\mathrm{CO}_{2}$ for use in greenhouses (Croezen et al., 2018). Other potential non-fuel CCU applications in Netherlands are much more limited in scope. Carbonate mineralization is only expected to account for a maximum of $200 \mathrm{kT} / \mathrm{y}$ even in the long-term, although this ultimately depends on the availability of waste streams like steel slag and fly ash. Likewise, the potential for $\mathrm{CO}_{2}$-based polymers is unlikely to surpass $50 \mathrm{kT} / \mathrm{y}$ unless novel markets for these polymers arise (Ecofys, 2017).

The total non-fuel CCU potential in Netherlands has been estimated as being of the order of 1.7-3 MT/y by 2030 (Krebbekx et al., 2012; Ecofys, 2017; Porteron et al., 2019). The magnitude of the discrepancy between this figure and the total $\mathrm{CO}_{2}$ availability can be understood by considering that the $\mathrm{CO}_{2}$ emissions resulting from fuel consumption in just the Dutch energy and manufacturing industries and construction amounted to $87.7 \mathrm{GT}$ in 2018 (RIVM, 2020). Nevertheless, the development of a $\mathrm{CO}_{2}$ supply grid can start with 'low hanging fruit' applications like 
horticulture and chemical synthesis, before being extended to larger-scale, longer-term CCS applications. Since the production of substantial quantities of electrofuels is only expected to be viable post-2040 (Malins, 2017; Searle and Christensen, 2018; Kranenburg et al., 2020), CCS is, as a minimum, a significant bridging solution until the time that CCU can realistically be expected to reach scale.

For CCU deployment, the first thing to consider is the location and size of the potential carbon sources and sinks. In Netherlands, the major point sources for $\mathrm{CO}_{2}$ emissions are located along the coast in the provinces of North Holland, South Holland and Zeeland. These include the Tata Steel plant in IJmuiden, the YARA Sluiskil fertilizer and chemicals plant and the Dow Benelux chemical plant in Hoek. Linking these concentrated $\mathrm{CO}_{2}$ emissions sources with potential $\mathrm{CO}_{2}$ sinks in the vicinity would therefore be a logical first step, although this should be done keeping in mind that trends such as an increase in renewable energy use and energy efficiency may lead to a decline in the availability of these sources in the future. The major emitters in the Randstad region are in relatively close proximity to chemical plants that could act as their customers for $\mathrm{CO}_{2}$. For instance, the 45 chemical companies based in the RotterdamRijnmond cluster have traditionally used petrochemical feedstock (Stork et al., 2018), but recycled $\mathrm{CO}_{2}$ from the nearby steel plant or power stations could be used in the methanol-to-olefins or urea plants that are present here.

Beyond this, the prospects of Dutch non-fuel CCU are unclear. For a start, there is a need for more comprehensive and accurate statistics regarding carbon flows in the Dutch economy. It has been estimated that only $63 \%$ of domestically produced carbon products stay in the Dutch economy, the rest being exported (Rutten, 2020). Even if the majority of these remaining products are reclaimed and subject to mechanical and chemical recycling, it is clear that there will be a serious shortfall in the local availability of recycled feedstock. CCU can potentially plug this gap, but whether this is techno-economically practical needs to be determined based on a granular examination of the application and its scale, which can only be done in the presence of more robust data. As things stand today, it seems fair to conclude that CCU will remain for a long time a niche application, at best a small adjunct to large-scale CCS deployment, albeit one that is likely to grow and to ultimately (post 2050) overtake CCS. This is, we believe, the balanced technical perspective on $\mathrm{CC}(\mathrm{U}) \mathrm{S}$.

\section{GOVERNMENTAL SUPPORT FOR CCS}

As evidenced by the description of the previous CCS project plans in Netherlands, the government is an important stakeholder in the successful implementation of CCS. The governments can employ different roles and policy instruments to enable, stimulate or to impose CCS projects (Slagter and Wellenstein, 2011). On the one hand, it can enable CCS projects by providing legal frameworks and it can further stimulate CCS by providing financial incentives. If necessary, for example when emissions reduction progresses too slowly, the government could also set obligatory binding reduction targets for sectors or companies.
Here they have a choice of either creating technology-neutral obligations, or of mandating specific options, like CCS. If sectors or companies fail to meet their obligations, governments can enforce compliance by means of financial punishments. So far, the Dutch government has steered clear of creating obligations, but it has implemented legal rules and introduced several financial instruments. These we will discuss in this section.

\section{Enabling CCS by Means of Fit-for-Purpose Legal Frameworks: EU and Dutch Rules}

Law is a crucial factor in enabling CCS deployment (Lipponen et al., 2017), because it can create an appropriate governancestructure, with clear roles, tasks and responsibilities while removing legal barriers. On a higher level, the European Union (EU) regulation is relevant for the Dutch legal framework. The CCS directive (2009/31/EC) contains important rules aimed at safeguarding safety and health conditions applicable in all member states as well as minimum requirements for storage permits, liability and roles and tasks. Furthermore, it can introduce necessary legal instruments, such as permits, rules concerning the protection of health and environment and rules for liability, for instance, in case of $\mathrm{CO}_{2}$ leakages.

The EU however emphasizes that the development of CCS "should not lead to a reduction of efforts to support energy saving policies, renewable energies and other safe and sustainable low carbon technologies, both in research and financial terms" (consideration 4). The EU determines that CCS is the permanent containment of $\mathrm{CO}_{2}$, with care taken to eliminate negative effects and any risk to the environment and human health as far as possible (article 1). According to the directive, the decision to employ CCS is decision of member states. Neither the Directive nor the Dutch Mining Act explicitly regulate (management and maintenance of) transportation, or pipelines. This suggests that operators have freedom in determining the conditions of transportation. Under certain circumstances, however, third-party access to this infrastructure must be permitted (article 21), yet the Dutch Mining Act contains no rules guaranteeing this access.

Member states can create additional requirements, depending on the national context. Netherlands has implemented the CCS directive into chapter 3 of the Mining Act. Below we will give the most important rules.

\section{Roles and Tasks}

The CCS directive identifies a number of roles and important tasks,: operator and as regulator. The storage operator is responsible to continuously monitoring the $\mathrm{CO}_{2}$ injection facilities, the underground storage complex and if necessary the surrounding environment to detect irregularities during operation and after closure of the storage site (article 13). The operator has to report on the results of the monitoring (article 14). Furthermore, the member states have to organize a inspections by competent authorities (article 15). The minister of Economic Affairs and Climate Policy is responsible for handling applications for permits, dealing with monitoring and liability 
costs, as well as closure of the site. He is also responsible in taking over accountabilities after closure.

\section{Permits}

Operators are required to obtain permits for exploration of potential storage sites as well as storage facilities (articles 5 and 6 CCS Directive). In order to obtain a permit, an operator must be financially sound, and provide proof of financial security (article 19). It must be moreover technically competent and able to reliably operate and control the site. A permit may also be withdrawn; in case $\mathrm{CO}_{2}$ leakage towards the overburden occurs or if significant irregularities occur (article 11). The permit can contain additional conditions, for instance relating to the total amount of $\mathrm{CO}_{2}$ stored.

According to the Dutch Mining Act, the Minister of Economic Affairs and Climate Policy grants the storage permit. An applicant of a permit must provide relevant information, such as a time frame for the injection of $\mathrm{CO}_{2}$, characteristics of the storage site and risk management procedures (articles $31 \mathrm{~b}$ and 31d). Once the minister has received an application for a permit, other parties will have the opportunity to also submit an application for the same area. The minister then decides, on the basis of the information provided in the applications, who will be granted the permit. This means that an exploration permit, leading to the identification of a suitable site, does not guarantee a storage permit.

\section{Leakages and Liability}

In case leakage or significant irregularities occur, the operator has to notify the competent authority, in the Dutch case the Minister of Economic Affairs and Climate Policy, and take necessary corrective measures. In case the operator is unable to do so, the competent authority will take over (article 16). In this case, the operator has to surrender emissions allowances under the Emissions Trading System (ETS) (Directive 2009/29/EC, 2009) for resulting emissions into the atmosphere for at least 20 years after obtaining the permit, or after closing the storage site (see below). However, in Netherlands the minister can decide to shorten or prolong this, albeit that the Mining Act does not provide any indicators for how this will be decided upon. This is therefore an uncertainty also with respect to ETS liability.

Liability for damages to the environment is dealt with by means of the Directive on Environmental Liability (Directive 2004/35/CE, 2004) and damage to health and property is dealt with at the member state level. In Netherlands, this is regulated by means of the Dutch Civil Code (article 6.162 and 6:174177). These provisions are general and do not pertain to CCS specifically. The length of liability for damages under these provisions differs from between 5 years after discovery of the damage to 20-30 years after the activity has caused damages. However, after a period of 30 years any liability under the Dutch Civil Code ends.

\section{Closure of Storage Sites}

When the conditions of the permit are met, for instance relating to the volume of $\mathrm{CO}_{2}$ stored, the storage site will be closed permanently. Upon closure, a post-closure plan is required, which has to be approved by the authority. In the case of Netherlands, the Minister of Economic Affairs and Climate Policy. After closure, all legal responsibilities for the site, including monitoring and corrective measures can be transferred to the competent authority after a period of 20 years. However, this is only possible in case the authority is convinced the $\mathrm{CO}_{2}$ is stored safely and a financial contribution by the operator has been made (article 18). This includes a financial contribution for monitoring efforts for at least 30 years, which contribution lies between 1 and 10 million euros. Operators are therefore at least for a period of 50 years responsible for monitoring. After this period, the responsibility is taken over by governmental authorities. Under Dutch rules, this period can however be shorter or longer depending on the judgment of the minister whether the $\mathrm{CO}_{2}$ is completely and permanently sealed. No further additional conditions with respect to the judgment have been provided, leaving the length of the period uncertain. The minister can moreover recover any costs resulting from a leakage from the permit holder beyond the 20 years in case the operators has not acted carefully (article $31 \mathrm{k}$ under 5).

\section{Analysis and Conclusion}

Broadly, the current legal framework offers clear roles, tasks and responsibilities. This framework makes it possible to obtain a license for a CCS project, but at the same time leads to a number of uncertainties. Firstly, the storage site permit procedure is a competitive one; there is no guarantee of 'first come, first serve'. If another project developer applies for a permit on the same location, the minister choses between the applicants. This of course stimulates the selection of the best possible project emerges, but for project developers, it creates uncertainty. After all, they must to do the exploratory work, which can already be costly, without any certainty that they will be able to develop the project further.

Secondly, the costs of liability, beyond the EU ETS rights, as well as the costs of monitoring are not clear beforehand. There are a number of exceptions the minister can make to shorten or prolong the period of costs for the operator. Thirdly, any third party seeking access to the existing transport infrastructure comes across a lack of rules, even though the EU mandates member states to create such rules. In order to ensure CCS implementation, the legislator could seek to remedy these uncertainties by removing them as much as possible, while still fostering safety and affordability of the technique. Financial policy instruments can also contribute to this.

\section{Financial Policy Instruments to Enable and Stimulate CCS}

In addition to creating the appropriate legal frameworks, the government can also play an active role in stimulating mitigation techniques by providing for financial incentives. These could include subsidies and taxes that render the GHG emissions less attractive, i.e. more expensive, than the implementation of the reduction techniques. Below we will discuss the available financial instruments in place in the EU and Netherlands: The EU Emissions Trading System and Dutch SDE ++ subsidy and carbon tax for industrial emissions. 


\section{EU Emissions Trading System}

The EU ETS covers $45 \%$ of all $\mathrm{CO}_{2}$ emissions in the EU (Directive 2009/29/EC, 2009; Regulation (EU) 2018/842, 2018). It provides a two-fold solution for the reduction of $\mathrm{CO}_{2}$ : (1) it lowers the cap on emissions each year by $1.7 \%$ (until 2020) and $2.2 \%$ (by 2030, although this will be higher depending on whether the EU Climate Law will be adopted) and (2) it puts a price on the remaining emission allowances. The remaining $55 \%$ of all $\mathrm{CO}_{2}$ emissions is covered by the effort sharing scheme (Decision No 406/2009/EC, 2009; Regulation (EU) 2018/842, 2018).

Under the EU ETS, emitters hold emissions permits (article 4, 2009/29/EC) based on which emissions allowances are awarded. Subsequently, these permit holders are obliged to take emissions reduction measures, amongst which CCS counts (Haan-Kamminga et al., 2010). With increasing prices for emissions allowances, reduction, including by means of CCS, becomes more attractive. In order to be able to claim this reduction, there needs to be a direct relationship between the emitter and the entity responsible for the permanent storage of the $\mathrm{CO}_{2}$. This is possible, as the permit holder may consist of a group of entities. However, this de facto requires all entities to be known at the time of application for a permit. This could be prevented by transferring the ownership of $\mathrm{CO}_{2}$, which is possible under the Dutch Civil Code (article 7:1-48).

The price for emissions allowances is volatile, for instance, in 2018 a sharp increase in the price was detected (Verbruggen et al., 2019). In order to prevent volatility and steep differences, the EU devised the Market Stability Reserve. Allowances are inserted into the reserve in times of surpluses, and released back into the market in case of shortages. In this way, steep increases in prices can be prevented by increasing the offer of allowances.

\section{SDE++ Subsidy for CCS}

The scope of the Dutch SDE++ subsidy (from Dutch Stimuleren Duurzame Energie, Stimulating Sustainable Energy) was broadened in 2020 from solely renewable energy techniques to including emission reduction techniques like CCS as well. Before this date, there were no national subsidies available for CCS.

As a result of negotiations between environmental NGOs and energy intensive industries (EII), subsidy for CCS under the Dutch Klimaatakkoord, subsidy for CCS is capped at a reduction of 7.2 $\mathrm{Mt} \mathrm{CO}_{2}$, out of the annual industry reduction target of 14.3 Mt (Klimaatakkoord, 2019). This was done in order to keep societal costs low and to stimulate industrial parties to find other sustainable solutions such as large-scale electrification and green hydrogen.
The SDE++ subsidy is collected by means of a surcharge on energy consumption (ODE, from Dutch Opslag Duurzame Energie), of all types of energy consumers, albeit with different contributions. Households and small and medium enterprises contribute $1 / 3$ rd of the costs, whereas larger businesses contribute $2 / 3$ rd of the costs. However, the ODE tariffs are largely regressive, and decrease with increasing energy consumption (Table 1):

SDE ++ subsidy is available only for the gap between the costs of the installation and the potential financial business case. The subsidy is given as a top-up on market prices, such that price risks are eliminated, but applicants compete for the subsidy, ensuring that the necessary subsidy decreases. Once $\mathrm{CO}_{2}$ can be reduced by means of CCS, companies enjoy a potential advantage since less EU-ETS rights are required. This gain, however, will be siphoned off by lowering the CCS SDE++ subsidy.

For CCS, the maximum subsidy is fixed per ton of reduced $\mathrm{CO}_{2}$, which can be rewarded for a period of maximum 15 years. Projects with an application for a lower subsidy than the fixed maximum are more likely to be rewarded. The total amount of SDE ++ subsidies available in 2020 was $€ 5$ billion. Of this, existing plants could receive up to $€ 39$ per avoided ton of $\mathrm{CO}_{2}$, and new capture installations (to be installed) for new plants up to $€ 76$ per avoided ton of $\mathrm{CO}_{2}$. New capture installations within existing plants can receive up to $€ 85$ per avoided ton of $\mathrm{CO}_{2}$. The 2020 SDE++ round ended in December, 2020. A total amount of $€ 6.4$ billion has been applied for, through 4112 applications. Of this, $€ 2.1$ billion within 7 projects have applied for CCS subsidy specifically. Since more subsidy has been requested than available, the Minister of Economic Affairs and Climate Policy will likely reward the cheapest reduction options, among which CCS is a contender. The final decisions are expected in the spring of 2021 .

\section{Carbon Tax for Electricity Production and Industrial Pollution}

Whereas the EU ETS puts a price on carbon emissions, many studies have indicated the potential prices of emissions allowances are too low for deep emissions reductions (DER) techniques (Tvinnereim and Mehling, 2018; Söderholm et al., 2019). Combined with the volatile prices, this does not create a stable investment trajectory. Both at the Dutch and European level, within its Green Deal, it has been proposed to introduce a carbon tax to supplement the ETS price (Klimaatakkoord, 2019). The Dutch carbon tax will start at 30 EUR per ton $\mathrm{CO}_{2}$ in 2021, increasing by $€ 10,56$ each calendar year, leading to a $\mathrm{CO}_{2}$ tax of $€ 125$ per ton $\mathrm{CO}_{2}$. Companies can deduct the costs of the EU ETS rights from this tax. This Act was accepted by Parliament

TABLE 1 | Overview of ODE tariffs.

\begin{tabular}{|c|c|c|c|c|c|}
\hline Electricity & $0-10,000$ kWh & $10,001-50,000 \mathrm{kWh}$ & 50,001 - 10 million kWh & $\begin{array}{c}>10 \text { million } \text { kWh non-business } \\
\text { related }\end{array}$ & $\begin{array}{c}>10 \text { million } \mathrm{kWh} \text { business } \\
\text { related }\end{array}$ \\
\hline & $€ 0.0300$ & $€ 0.0411$ & $€ 0.0225$ & $€ 0.0004$ & $€ 0.0004$ \\
\hline \multirow[t]{2}{*}{ Natural gas } & $0-170.000 \mathrm{~m}^{3}$ & $170,001-1$ million $\mathrm{m}^{3}$ & $>1-10$ million $\mathrm{m}^{3}$ & $>10$ million $\mathrm{m}^{3}$ & \\
\hline & $€ 0.0851$ & $€ 0.0235$ & $€ 0.0232$ & $€ 0.0232$ & \\
\hline
\end{tabular}


in November 2020. In December 2020, the Dutch Senate also adopted the proposal, ensuring its implementation.

\section{Analysis and Conclusion}

Since the implementation of the EU ETS, producers of $\mathrm{CO} 2$ have steadily reduced their emissions, with a reduction of $20 \%$ achieved at the EU level in 2020, relative to 1990. Combined with the increasing price of ETS rights, this instrument has been and can be further effective in reducing $\mathrm{CO}_{2}$ emissions within the EU, for instance by means of CCS. The current legal framework in Netherlands ensures that permits can be obtained for CCS projects.

Recently, two important financial policy instruments have been introduced to further stimulate CCS. Their importance can be understood by remembering that the legal framework was already in place when the ROAD project was being undertaken, with the lack of appropriate financial instruments being the decisive factor in its abandonment. Since Porthos can contribute substantially to industrial emissions reductions, and parties, including EII and environmental organizations, have agreed that CCS is vital, the Dutch government has widened the scope of the SDE ++ subsidy to include CCS, albeit with some restrictions: a cap of 7.2 Mt per year, a subsidy for maximum 15 years and a maximum tariff per avoided ton of $\mathrm{CO}_{2}$. Combined with the introduction of the industrial carbon tax, which is likely to follow soon, reduction techniques are thus financially stimulated. Yet, of course, an important share of the costs will fall onto the Dutch EII. As the aim is to leverage public support and mobilize private investment in CCS, it is important to assess possible scenarios for company investments.

\section{INVESTMENT UNCERTAINTIES OF CCS}

It is abundantly clear that the costs of CCS are still a significant obstacle towards its large scale implementation (Budinis et al., 2018). The Global CCS Institute has provided an overview of the two most important cost components of CCS: investment and operational costs (Irlam, 2017). Investment costs relate to the initial investment in the capture plant, both for the design of the particular industrial process and for the installation of the plant. These are estimated to be between 20 and $110 €$ per ton of $\mathrm{CO}_{2}$ capture capacity over a range of industries (Budinis et al., 2018). Operational costs fall into three categories: fixed and variable operational and management costs and energy prices. The fixed operational costs are typically estimated at 5\% of all investment costs and include salaries, administration and overhead costs (Kuramochi et al., 2012; Yao et al., 2019) but importantly do not include interest and financing costs for the initial investments. Variable costs include the costs of labor, energy and inputs, especially in the capture process and are estimated to be around 60-80 €/ton of captured, transport ready $\mathrm{CO}_{2}$ (Budinis et al., 2018; Gardarsdottir et al., 2019). Operational costs also extend to the operation of the transportation infrastructure; transportation, injection, storage and monitoring. Adding all this up (to 80-90 $€ /$ ton), it is abundantly clear that at current $\mathrm{CO}_{2}$ prices of about
$25 € /$ ton, there currently is no profitable business case for CCS. At this price, even the variable costs cannot be recovered, let alone the fixed costs and a reasonable return on the initial investment. Low $\mathrm{CO}_{2}$ prices played no significant role in the decision to abandon the Barendrecht project but were a decisive factor in the ROAD-project.

Of course, $\mathrm{CO}_{2}$ prices are expected to rise in the future as deep cuts in $\mathrm{CO}_{2}$ emissions necessarily call on a wide range of technical options, many of them more expensive than CCS (Wijnia and Croon, 2018). Also, as CCS becomes more common, early adopters may be better positioned to supply others with CCS technology and consulting, creating new markets and business models. One might argue that these are reasons for companies to start investing in CCS projects even if the business cases for their first projects are negative. It is intuitive that prospects for growth would improve the business case for CCS, but it is challenging to quantify such prospects and assess whether they are sufficient to make the case for CCS "Different this Time". In what follows we present an economic analysis of a CCS project that will give us a sense for the driving factors in the business case for CCS.

\section{The Private Business Case for CCS - An Example}

Consider the case of a steel company that invests in a carbon capture project worth 250 million $€$. This includes the cost of capture, onshore transport, and compression equipment. Assuming a construction period of 1 year, the project can capture $1 \mathrm{Mt} \mathrm{CO}_{2} /$ year for 30 years at a cost of $€ 70$ million/year (including a "handling fee" of $2 € / \mathrm{t} \mathrm{CO}_{2}$ to transport and store $\mathrm{CO}_{2}$ ). In the process industry, the total operations and maintenance $(\mathrm{OM})$ cost is typically $5 \%$ of capital expenditures. For simplicity we assume that the pre-investment spending is fixed and risk-free and the discount rate is set at $5 \%$. The benefits for the project are the costs of $\mathrm{CO}_{2}$ emission allowances that would have to be bought without CCS. This benefit is the quantity captured times the price of $\mathrm{CO}_{2}$ emission rights. As our baseline we assume the historical trend of $\mathrm{CO}_{2}$ prices with an annual average growth rate of $7 \%$ and volatility of $50 \%$ from the current

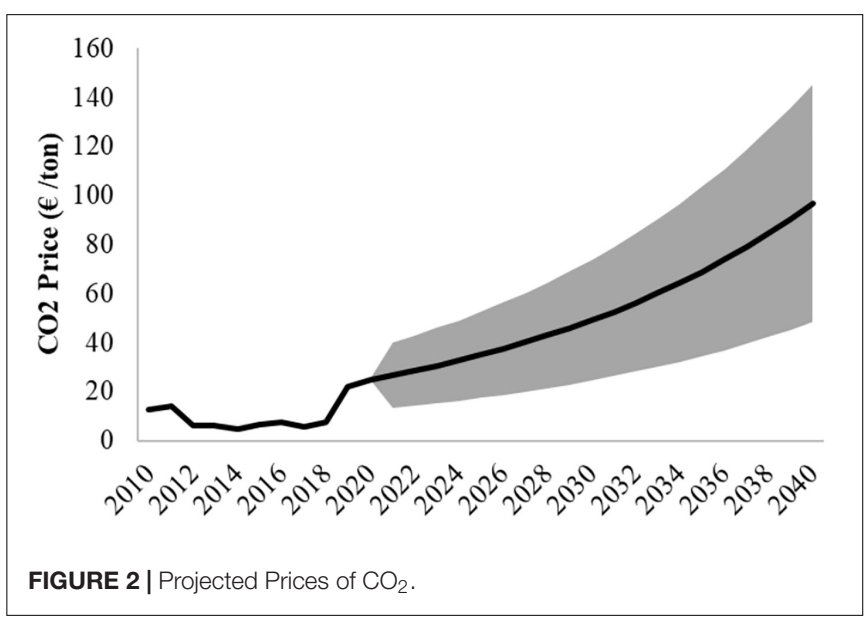


$25 € / \mathrm{tCO}_{2}$ (see Figure 2). The avoided $\mathrm{CO}_{2}$ is $1 \mathrm{Mt} / \mathrm{y}$. We set the decision horizon for the firm, admittedly arbitrarily, to 20 years. The key parameters for the computations are listed in Table 2.

The net present value for this project is negative $(-132 \mathrm{M} €$, for full computation see Supplementary Appendix 1). At the average $7 \%$ growth rate in $\mathrm{CO} 2$ prices the price would cover marginal costs only in 2036 and at a 5\% discount rate the profits in remaining years are insufficient to recuperate the capital costs ${ }^{1}$. It also means that the company should not invest in CCS until the $\mathrm{CO}_{2}$ price covers the costs (the value of the project is zero if we start at $31 € / \mathrm{tCO}_{2}$ and project the $7 \%$ increase to a maximum of $200 €$ per ton for 30 years. See Supplementary Appendix 1). In order to appreciate the opportunity that CCS presents in mitigating future $\mathrm{CO}_{2}$ pricing or other regulation, it is useful to consider the investment not merely on the basis of its expected net present value, but consider it as a 'real option'. Having the opportunity but not the obligation to invest in this project, is like having an option on buying an asset that yields a benefit equal to the uncertain $\mathrm{CO}_{2}$-price times from the $1 \mathrm{Mt}$ of avoided emissions minus marginal costs for the 30 year project duration.

Although the project is not interesting at today's prices and historical trend growth, the possibility that it will become profitable in the future makes the option to invest in this project valuable. Investing in the project when $\mathrm{CO}_{2}$ prices hit the break-even level, however, would not be rational. The project would then yield a very low profit, while the firm could gain a lot by waiting to see where prices actually move.

This "real option" can be valued like a financial call option using the famous Black and Scholes formula and turns out to be worth $95 \mathrm{M} €$ (see Supplementary Appendix 1). Under current prices the early adoption of CCS technology is not optimal, and firms will wait because $\mathrm{CO}_{2}$ prices are uncertain and expected to increase over time (Abadie and Chamorro, 2008; Heydari et al., 2010; Knoope et al., 2015).

${ }^{1}$ Note we assume that the firm only operates when the benefits exceed the marginal operational costs.

TABLE 2 | Parameters of net present value and option valuation model in step 1.

\begin{tabular}{|c|c|c|c|}
\hline Symbol & Variable & Value & Source \\
\hline I & CAPEX & $250 \mathrm{M} €$ & Roussanaly, 2019 \\
\hline VC & Variable Costs & $57.5 \mathrm{M} \mathrm{ACO}_{2}$ & Roussanaly, 2019 \\
\hline FC & Fixed Cost & $12.5 \mathrm{M} € /$ year & \\
\hline C & Capacity & $1 \mathrm{MtCO}_{2} /$ year & $\begin{array}{c}\text { Value assigned for the } \\
\text { valuation }\end{array}$ \\
\hline $\mathrm{T}$ & Lifetime & 30 year & Morfeldt et al., 2015 \\
\hline r & Discount Rate & $5 \%$ & $\begin{array}{l}\text { Knoope et al., 2015; } \\
\text { Yao et al., } 2019\end{array}$ \\
\hline$P_{0}$ & Initial $\mathrm{CO}_{2}$ price & $25 € / \mathrm{tCO}_{2}$ & Gerlagh et al., 2020 \\
\hline$\alpha$ & Trend & $7 \%$ & $\begin{array}{c}\text { Calculated from } \\
\text { Gerlagh et al., } 2020\end{array}$ \\
\hline$\sigma^{2}$ & Volatility & $50 \%$ & $\begin{array}{c}\text { Calculated from } \\
\text { Gerlagh et al., } 2020\end{array}$ \\
\hline
\end{tabular}

\section{Investing Now to Benefit Later}

We can also consider a further extension, in which we consider the investment in a pilot CCS project as creating the opportunity to pursue valuable follow-up projects if market conditions turn out favorably. With Netherlands' target of reducing carbon emissions by $49 \%$ by 2030 , CCS could lead towards that goal by taking a share of up to $20 \mathrm{Mt} \mathrm{CO}_{2}$ annual emission reductions by 2030 (Hellemans, 2018). If this is to be achieved (in Netherlands and elsewhere), a market for CCS expertise and experience must emerge. Investing in CCS now may give firms a head start in these future markets. As the market for CCS grows, innovation, economies of scale and learning-by-doing reduce CCS technology cost over time. We capture both market growth and technology learning by again considering our steel firm investing in a pilot CCS project with the parameters as described in step 1. However, we now assume the project positions the firm to benefit at a later stage, for which we assume a larger market size for CCS. In that phase, the firm has the option of selling its technology or providing consultancy and CCS services to other firms entering the market later. The key parameters for the computations are listed in Table 3.

If our firm invests in the pilot CCS project with a value of $-132 \mathrm{M} €$ in the first phase, the estimated value of selling the "know-how" given the uncertainty in the market size on the second phase in our model is only $82 \mathrm{M} €$ (see Supplementary Appendix 1). As the firm can only profit from the emerging market for CCS technology after exercising the pilot project in the first stage, the value of those profits should be greater than the negative value of the pilot plant. The result therefore implies that the firm should not investment in CCS as an investment in know-how. In other words, the expected additional gains from the commercialization phase are not large enough to recover the losses from the pilot project. Along with the uncertainties in $\mathrm{CO}_{2}$ prices and in social and political pressures discussed in previous cases, we show in step 3 that investment decisions for CCS will be low due to the uncertainty in technological learning and the uncertain evolving market size for CCS. Here, our model reveals that policy is necessary to attain a certain level of maturity for this technology. CCS needs frontrunners who are willing to take the risk in starting CCS investment projects and the pioneers might

TABLE 3 | Additional parameters for option valuation in step 2.

\begin{tabular}{|c|c|c|c|}
\hline Symbol & Variable & Value & Source \\
\hline NPV & Net present value of CCS & $-132 M €$ & $\begin{array}{l}\text { See assumptions in } \\
\text { Step } 1\end{array}$ \\
\hline Ms & CCS market size & 20 MtCO2/year & Hellemans, 2018 \\
\hline Cf & Consultancy cost & $4.5 \%$ of CAPEX & DECARBit, 2007 \\
\hline Lr & Technology learning & $\begin{array}{c}-17 \% \text { change in } \\
\text { CAPEX }\end{array}$ & Irlam, 2017 \\
\hline r & Discount rate & $5 \%$ & $\begin{array}{l}\text { Knoope et al., 2015; } \\
\text { Yao et al., } 2019\end{array}$ \\
\hline C & Capacity & $1 \mathrm{MtCO}_{2} /$ year & $\begin{array}{l}\text { Value assigned for the } \\
\text { valuation }\end{array}$ \\
\hline t & Commercialization phase & 10 years & $\begin{array}{c}\text { Value assigned for the } \\
\text { CCS commercialization } \\
\text { phase }\end{array}$ \\
\hline
\end{tabular}


accept some of the losses from the pilot CCS projects to build a competitive advantage in the long run. Successful business cases for CCS will then generate more opportunities to continue the cycle creating a good market and more mature technology.

Our model extension shows that larger projected future markets will promote more CCS investments. Notably, the impact of more uncertainty in $\mathrm{CO}_{2}$ prices now works positively on the business case. The intuition is that higher uncertainty in $\mathrm{CO}_{2}$ prices now increases the upside (prices may move favorably, increasing demand in CCS markets), while it does not affect the downside (if the market is small the firm will decide not to enter it and losses can never be more that the $-132 \mathrm{M} €$ of the pilot). However, in our calculation, the business case is still not positive and the government still has a role to play in closing the gaps that exists.

\section{A Firm Social and Political Commitment to Ambitious Climate Mitigation Policies}

We can extend our case by considering the possibility that the government imposes CCS as a condition for continuing operations at some unknown time in the future. We assume our industrial firm invests in CCS before that time in order to be able to continue operations when the policy is implemented. If the firm has an operational income of $3000 \mathrm{M} €$ per year, not investing in CCS in time puts that entire operational income at risk. The key parameters for the additional computations are listed in Table 4.

If the firm invests in CCS, the discounted income for 30 years of operation decreases from $48423 \mathrm{M} €$ to $48291 \mathrm{M} €$ (see Supplementary Appendix 1). Not investing in CCS, however, implies the firm risks having to shut down altogether. If we assume the probability of such a policy being implemented is $5 \%$ per year. This implies the probability that it happens within 10 years is $40 \%$ and within 20 years $64 \%$ and that risk reduces the value of the firm to $22020 \mathrm{M} €$ (see Supplementary Appendix 1). This is under the assumption that the firm has to stop operations altogether if it has not invested when the policy is implemented.

If we assume that a 1 year of revenue is lost to install the CCS capture technology once the policy is implemented, the firm would lose $1420 \mathrm{M} €$ (see Supplementary Appendix 1). Clearly such a loss justifies investing in CCS. The results imply that the government obligation improves the case for investing in a CCS project. We can show in step 2 that the value of CCS thus depends crucially on the uncertainty over the timing and intensity of social and political pressures to reduce emissions.

TABLE 4 | Additional parameters for option valuation in step 3.

\begin{tabular}{|c|c|c|c|}
\hline Symbol & Variable & Value & Note \\
\hline NPV & Net present value & $-132 \mathrm{M} €$ & $\begin{array}{l}\text { See assumptions in } \\
\text { Case } 1\end{array}$ \\
\hline $\mathrm{Pr}$ & Probability & $5 \% /$ year & $\begin{array}{l}\text { Probability that the } \\
\text { policy will be } \\
\text { implemented }\end{array}$ \\
\hline S & $\begin{array}{c}\text { Annual operational } \\
\text { income }\end{array}$ & 3000 M €/year & $\begin{array}{l}\text { Value assigned for the } \\
\text { calculation }\end{array}$ \\
\hline
\end{tabular}

From the valuation result, our model predicts that more CCS projects will be viable in Netherlands when the government firmly commits to CCS, or firms see rising social pressures that may lead to a legal requirement for CCS to continue operations sometime in the future. As a corollary, in the absence of such commitment, incentives are weak. It should also be noted that the government must first secure a more stable $\mathrm{CO}_{2}$ price and provide predictable and secure tax incentives and subsidies. Otherwise, companies will suffer serious economic losses and may choose to avoid these altogether by leaving the country or the industry, effectively eliminating the benefits for the climate.

\section{Analysis and Conclusion}

Starting from a stand-alone CCS project that is only based on the market price of $\mathrm{CO}_{2}$, our model shows that private investment in CCS is unlikely to emerge. Also, CCS is not a convincing business case for frontrunners seeking to benefit from their "know-how" in future markets for CCS. However, adding the possibility of a government policy that imposes CCS as a precondition for continued operations, creates strong financial incentives to invest. Our analysis also shows that the rational waiting period to invest in CCS can be reduced by implementing policies requiring firms to operate with CCS, creating a more predictable trend in or increasing $\mathrm{CO}_{2}$ prices, and by promoting future CCS markets to create incentives for technology learning from investing earlier. Implementing a $\mathrm{CO}_{2}$ tax on top of the EU-ETS to create a predictable long run outlook on $\mathrm{CO}_{2}$ prices, is therefore a crucial step. With that tax, things may turn out to "be different this time". A firm commitment to require CCS combined with (carbon tax financed?) subsidies to would allow firms to absorb the losses involved and seems to be needed to get private investment in CCS in Netherlands off the ground.

\section{SOCIETAL ACCEPTANCE OF CCS}

Although hard to quantify like cost-benefit and real option valuation models, societal acceptance, or the lack thereof, has proven to be a decisive factor in the implementation of CCS, as illustrated by two Dutch cases above (Brunsting et al., 2011; Kuijper, 2011; Terwel and Daamen, 2012; van Os et al., 2014; van Egmond and Hekkert, 2015; Jones et al., 2017). The role of societal acceptance is therefore a central focus point for academics, policy makers and potential investors.

The academic literature has focused on public acceptance of CCS as a climate change mitigation technique (van Alphen et al., 2007; Terwel and Daamen, 2012; Selma et al., 2014), acceptance at the project level (Brunsting et al., 2011; Kuijper, 2011; Terwel and Daamen, 2012; van Os et al., 2014; van Egmond and Hekkert, 2015), some focusing on specific countries (Fischedick et al., 2009; Toikka et al., 2014; Gough et al., 2018). Arning et al. (2019) found that CCU is more positively perceived than CCS by the public in Germany. Huijts et al. (2012) have developed a technology acceptance framework on the basis of psychological factors, which has been adopted by Selma et al. (2014) specifically for acceptance of CCS. From this, 13 concepts and corresponding definitions can be derived (Table 5). 
TABLE 5 | Overview of CCS technology acceptance framework.

\begin{tabular}{|c|c|}
\hline Concept & Definition \\
\hline \multicolumn{2}{|l|}{ Personal factors } \\
\hline Knowledge & Awareness of CCS, self-assessed knowledge and objectively assessed knowledge \\
\hline Experience & $\begin{array}{l}\text { Direct experience with CCS, but also with related technologies (e.g., fossil fuel extraction, } \\
\text { underground gas storage) }\end{array}$ \\
\hline Outcome efficacy & Belief that one own behavior affects the implementation of CCS \\
\hline \multicolumn{2}{|c|}{ Role of CCS as climate mitigation technique and alternatives } \\
\hline Problem perception & Awareness of climate change and consequences if no new technologies are implemented \\
\hline Energy context & Relates to the current energy mix and the possible alternatives to CCS \\
\hline Perceived benefits & All potential benefits attributed to CCS: for oneself, society and the environment \\
\hline Affect & Feelings towards CCS, with positive and negative affect being two distinct dimensions \\
\hline \multicolumn{2}{|c|}{ Factors relating to (organization of) projects } \\
\hline Trust & Trust in stakeholders. In the case of CCS typically project developers, government, NGOs \\
\hline Fairness, which includes: & $\begin{array}{l}\text { Two types: Procedural fairness, such as fairness of decision processes and distributive fairness, } \\
\text { including distribution of costs, risks, benefits }\end{array}$ \\
\hline Perceived costs & Financial costs for individuals and society, and psychological costs (e.g., effort) \\
\hline Perceived risks, including: & Potential risks to the health and safety of both humans and nature \\
\hline Interference with nature & $\begin{array}{l}\text { Perception of interference with the environment for implementation or tampering with the } \\
\text { subsurface. This is closely connected to perceived risks }\end{array}$ \\
\hline \multicolumn{2}{|c|}{ These 12 factors combined may influence: } \\
\hline Acceptance/attitude & $\begin{array}{l}\text { Expressed acceptance ("I would accept CCS") and revealed acceptance, which is displayed by } \\
\text { engagement in activities for or against CCS }\end{array}$ \\
\hline
\end{tabular}

These factors are also highly relevant for Netherlands. Below we will assess how each of these factors relate to the overall acceptance of CCS in Netherlands and how this knowledge can be or is currently used by Dutch policy makers and investors in taking up new CCS projects. To this end, we have adapted the table from Selma et al. (2014), to group factors relating to the view of individuals, pertaining to knowledge and experience (see 'personal factors'), the role of CCS as a climate mitigation technique and possible alternative solutions and factors relating to the organization of projects. We base our assessment on a stateof-the-art literature review of CCS projects in Netherlands. This includes 16 studies, published between 2007 and 2020, of which the vast majority (15) has been published between 2007 and 2014 (see Annex II for the overview). The fact that these articles are relatively older, reveals that little is known about the current opinion of the public on CCS in Netherlands, in its current form: offshore and only with industrial carbon sources.

\section{Personal Factors Influencing the Acceptance of CCS}

Generally, the knowledge and awareness of CCS as a potential climate change mitigation is high in Netherlands. In a 2013 study $84 \%$ of the respondents knew about CCS. This can be explained by the Barendrecht case, as this received much media attention around 2010 (Ashworth et al., 2013). This also means that parts of the Dutch have some experience with CCS, directly or through media attention (de Best-Waldhober et al., 2012). It is currently unknown whether people believe they can affect the implementation of CCS.

\section{Role of CCS as Climate Mitigation Technique and Alternative Solutions}

On a more general level, the Dutch public is aware of the problem of climate change, and what is necessary in order to mitigate its consequences as much as possible. In a 2020 study by Netherlands Institute of Social Research, it was found that $77 \%$ of the respondents are aware of climate change, and 49\% of the respondents are concerned about this issue (SCP, 2020). There are no recent studies on attitude or acceptance of CCS in Netherlands. However, in 2018 a report on prospects of Porthos showed that the ROAD project did not receive much negative notice and it is therefore likely that a new offshore project will not give rise to strong negative attention (Warmenhoven et al., 2018). Whether this also holds true for other projects, such as Athos, or all projects combined, is to be seen. Because little is known about the publics and affect opinion on CCS, there is also little information about perceived benefits in light of climate change.

Societal support can also depend on the carbon source, i.e. where the carbon is captured and therefore whether acceptance depends on or is supported by technology preferences. Dütschke et al. (2016) found that carbon capture at biomass plants was perceived more positively than captured at CFPP, as was also shown by de Best-Waldhober et al. (2009). This point is also raised by Gemeynt in their 2018 report, in response to $\mathrm{ROAD}$ and the plan to capture carbon at the Dutch CFPP. Since ROAD, a political decision has been made to phase out all coal-generated electricity, by means of a prohibition to generate electricity with coal domestically (Wet verbod op kolen). The four remaining Dutch CFPP therefore can no longer use coal latest by 2030 (Akerboom et al., 2020). Owners can however rebuild their CFPP into biomass plants and continue to generate electricity beyond that date.

Other key stakeholders, such as NGOs, have scrutinized CCS as a mitigation technique, regardless of the carbon source. CCS, it is as argued by NGO's, concerns an end-of-the-pipe solution, with little added benefits to society. It can moreover maintain the status quo of the fossil fuel industry, simply allowing them to deal with their waste products but not with the original 
processes producing this waste (Swennenhuis et al., 2020). To this end, some have argued in the past that CCS should not be implemented. In Netherlands this discussion is also present. However, the importance of CCS as mitigation technique is increasingly being recognized. When CCS was discussed during the negotiations of the Dutch Klimaatakkoord, it was therefore agreed upon to aim to implement CCS, but to cap potential governmental subsidies to 7.2 Mt annually, in order to prevent high societal costs (see section "Financial Policy Instruments to Enable and Stimulate CCS”).

\section{Factors Relating to the Organization of Projects}

Acceptance of a new technology can also be related to specific projects, how they are organized, whether and how the public is consulted, whether the public trusts the key players involved and if there are perceived costs and risks connected to this project.

Fairness, both procedurally and distributionally, is essential for the acceptance of projects. Research into the case of Barendrecht revealed that the resistance did not solely arise from risk perceptions, but also from a lack of trust in the central government (the project commissioner) and Shell (the operator), and a perceived unfairness of the decision-making process and lack of citizen involvement therein. These three factors have also been identified by other studies as significant contributors to societal acceptance (Terwel et al., 2011; Terwel and Daamen, 2012; Xenias and Whitmarsh, 2018; Arning et al., 2019). It is found that a joint effort of government, industry and NGOs for communication improves public perception of CCS, especially when there is transparency and openness about the process and the results (Gross, 2007; ter Mors et al., 2009) as well as having the opportunity to provide input during a decision-making process (Terwel et al., 2010). This could also increase trust in stakeholders, companies and government when implementing CCS. Therefore, new studies aim to develop strategies to introduce social acceptance into the design of CCS supply chains (Federico et al., 2020), in order to integrate this aspect early into the decision-making process.

The perception of costs, which is also closely related to the question of whether there are suitable and cost-effective alternatives to CCS, can be captured in willingness to pay for the technique. Increased costs of the energy system may have a negative impact on the perception of CCS (Shackley et al., 2009). Studies in countries like Germany have shown the amount or percentage of increased energy bills people were willing to pay if it led to the successful implementation of CCS (Kraeusel and Möst, 2012). A comparable study for the Dutch context has not yet been performed. Yet, the ODE tariffs, as paid for by small and large end-users towards the SDE ++ subsidy are organized in such a way that only the business contribution is employed for the CCS subsidy. The contribution of smaller end-users is put towards renewable energy techniques. This ensures that households do not contribute towards reduction obligations of industry and larger businesses, in order to foster societal acceptance.

The perception of risks is evidently important for the support of CCS projects. CCS projects cannot guarantee that a leakage will never occur. Given the close vicinity of Barendrecht to the CCS project, many people felt unsafe (Brunsting et al., 2011; Kuijper, 2011; Upham and Roberts, 2011; Terwel and Daamen, 2012; van Os et al., 2014; van Egmond and Hekkert, 2015). Previous studies have showed that people feel more comfortable when a CCS project is further away from where they live due to safety concerns (Miller et al., 2007, 2008; Midden and Huijts, 2009; Chen et al., 2015). The experiences with onshore CCS projects have led to the decision to move CCS offshore (Swennenhuis et al., 2020), and a first attempt was made with the ROAD project, but this project failed due to a lack of business case, caused by low carbon prices (Read et al., 2019).

\section{Analysis and Conclusion}

From this survey of the state of affairs with respect to societal acceptance, we conclude acceptance of CCS is tacit rather than explicit. There is the expectation that offshore CCS will receive little negative attention. This appears justified by the lack of attention to and public interest for ROAD, but - beyond that (Warmenhoven et al., 2018) - it is not supported by empirical evidence. This means that there is no indication of whether Porthos will receive negative attention, or Athos, or all the CCS projects combined. This is a step forward compared to the earlier explicit rejection of onshore storage as well as of electricity production as carbon source.

There is little empirical evidence for large-scale implementation of CCS in a country context, but rather there is evidence for general attitude towards CCS or specific CCS projects, which in the Dutch context has aged already. A lot of key elements in building public support, however, are missing and/or lack empirical data. This is therefore an important knowledge gap in Netherlands, and more research into different scenarios (onshore/offshore, small-scale/large-scale) of CCS deployment is necessary in order to get a clearer understanding of the public acceptance of CCS developing beyond individual projects to an 'industry' and a portfolio of projects.

\section{ANALYSIS - DIFFERENT THIS TIME?}

In this paper we have analyzed the case of CCS for Netherlands. We surveyed the history of CCS in Netherlands and reviewed the reasons why a number of CCS projects were canceled. We then considered aspects of CCS feasibility - technical, legal, economic and societal - to bring us to a final analysis of the lead question: Different this time?

It has long been clear that carbon capture and storage offers significant potential to reduce emissions on a short to medium time scale, in particular in the cement, steel and petrochemical industry, in thermal power generation and in waste-to-energy facilities (Global CCS Institute, 2019). Technically, CCS is a straightforward proposition: $\mathrm{CO}_{2}$ separation from gasses, including from flue gasses, is a mature technology (Vosbeek and Warmenhoven, 2007); $\mathrm{CO}_{2}$ transport through pipelines and its injection in the subsurface is proven.

However, the notion that it is better to store $\mathrm{CO}_{2}$ in the underground than to vent it into the atmosphere, obvious as 
it may seem to some, is not uncontested. CCS however has faced several challenges towards implementation in the past, societal resistance led to the cancelation of two projects and the ROAD project failed due to a lack of business case. Since these projects, developments have led to changes: the carbon source will be restricted to industrial emissions alone, there are new financial instruments to stimulate CCS and there will be no more onshore CCS projects. In that sense, some factors influencing the successful implementation of CCS are indeed different this time.

Yet, some other issues persist: large uncertainties with respect to the business case, despite the introduction of the financial instruments, remain and may impact or effectiveness on the business case for CCS projects. Section "Governmental Support for CCS" highlights that elements of a fit-for-purpose legal frameworks are still lacking and that there are no binding targets for industry CCS, necessitating the use of CCS over other mitigating techniques. In that sense, not all factors are different this time.

One the biggest unknown factors at this stage concerns the societal attitude towards CCS under these, partly new, conditions. Conclusion of research in the past have aged, especially in light of the new conditions. It appears that there is no active resistance towards offshore CCS, yet we would like to point out that this is not the same as active support and the potential effects of the societal attitude are largely unknown.

Perhaps a better question for future research concerns the following: "How much CCS, and for how long?", for which there is no technical answer. An answer must be provided in the form of a socio-technical narrative in which the full set of prospects for carbon abatement technologies and their development over time are put in the context of societal needs of energy, industry and economy.

Looking back at the history of CCS over the past decades we must conclude that there never was a socio-technical narrative that was sufficiently compelling to garner broad support, nor was the narrative sufficiently stable over time.

Apart from a shift from power sector to industrial emissions, the core narrative of CCS is unaltered. It remains a transition measure, deemed crucial in the short and medium term, now especially in view of the fact that industry has processes that cannot be electrified and decarbonized fuels will not be sufficiently available for a long time. Once again, the argument in favor of CCS is that its deployment offers the possibility of rapidly

\section{REFERENCES}

Abadie, L. M., and Chamorro, J. M. (2008). European CO2 prices and carbon capture investments. Energy Econ. 30, 2992-3015. doi: 10.1016/j.eneco.2008.03. 008

Akerboom, S., Botzen, W., Buijze, A., Michels, A., and van Rijswick, M. (2020). Meeting goals of sustainability policy: CO2 emission reduction, costeffectiveness and societal acceptance. An analysis of the proposal to phase-out coal in the Netherlands. Energy Policy 138:111210. doi: 10.1016/j.enpol.2019. 111210

Arning, K., Offermann-van Heek, J., Linzenich, A., Kaetelhoen, A., Sternberg, A., Bardow, A., et al. (2019). Same or different? Insights on public perception and acceptance of carbon capture and storage or utilization in Germany. Energy Policy 125, 235-249. doi: 10.1016/j.enpol.2018.10.039 and massively reducing emissions, above and beyond what can be done through other means, notably electrification.

The question it raises is to what extent its deployment gives fossil fuels a new lease on life, thereby standing in the way of renewables deployment, or slowing it down, in other words, maintaining the status quo. All agree that this should not be so; but, those in favor of CCS say it will not do so and those against say it will. In so far as CCS is accepted, it is as a transition measure, but how large the role for CCS is in the transition and how long the transition will be is still a matter of debate.

Lastly, perhaps the two most significant difference between a decade ago and today is the following: There is far greater active support from the government for CCS, it being one of the most important means for Netherlands to deliver on its 2030 emissions target. It is one of the most important means for Netherlands to deliver on its 2030 emission target. Perhaps the state of affairs is best summed up by avoiding the word acceptance and saying that CCS appears to be tolerated but not embraced. Empirical evidence on what to expect is essentially absent: the journey to CCS deployment beyond single, isolated projects is one into a societal terra incognita.

\section{AUTHOR CONTRIBUTIONS}

SA and SW suggested the topic of the manuscript. SA wrote Sections "Governmental Support for CCS" and "Societal Acceptance of CCS," and co-wrote Sections "Introduction" and "A Brief History of CCS in Netherlands and Europe." SW co-wrote Section "A Brief History of CCS in Netherlands and Europe" and proof-read the article. AM wrote Section "Technology Options: CCS, CCU, and CC(U)S." CA and MS co-wrote Section "Investment Uncertainties of CCS." GK wrote Section "Analysis - Different This Time?" and co-wrote Section "Introduction," and provided guidance for the manuscript. All authors provided critical feedback on all sections.

\section{SUPPLEMENTARY MATERIAL}

The Supplementary Material for this article can be found online at: https://www.frontiersin.org/articles/10.3389/fenrg. 2021.644796/full\#supplementary-material

Ashworth, P., Bradbury, J., Wade, S., Ynke Feenstra, C. F. J., Greenberg, S., Hund, G., et al. (2012). What's in store: lessons from implementing CCS. Int. J. Greenhouse Gas Control 9, 402-409. doi: 10.1016/j.ijggc.2012. 04.012

Ashworth, P., Einsiedel, E., Howell, R., Brunsting, S., Boughen, N., Boyd, A., et al. (2013). Public preferences to CCS: how does it change across countries? Energy Proc. 37, 7410-7418. doi: 10.1016/j.egypro.2013.06.683

Brunsting, S., Best-Waldhober, M. D., Feenstra, C. F. J., and Mikunda, T. (2011) Stakeholder participation practices and onshore CCS: Lessons from the dutch CCS case barendrecht. Energy Proc. 4, 6376-6383. doi: 10.1016/j.egypro.2011. 02.655

Budinis, S., Krevor, S., Dowell, N. M., Brandon, N., and Hawkes, A. (2018). An assessment of CCS costs, barriers and potential. Energy Strategy Rev. 22, 61-81. doi: 10.1016/j.esr.2018.08.003 
Carbon Capture and Sequestration Technologies Program at MIT (2016). ROAD (Rotterdam Opslag en Afvang Demonstratieproject) Fact Sheet: Carbon Dioxide Capture and Storage Project. Available online at: https://sequestration.mit.edu/ tools/projects/maasvlkte.html (accessed March 10, 2020).

Chauvy, R., Meunier, N., Thomas, D., and Weireld, G. D. (2019). Selecting emerging CO2 utilization products for short- to mid-term deployment. Appl. Energy 236, 662-680. doi: 10.1016/j.apenergy.2018.11.096

Chen, Z.-A., Li, Q., Liu, L.-C., Zhang, X., Kuang, L., Jia, L., et al. (2015). A large national survey of public perceptions of CCS technology in China. Appl. Energy 158, 366-377. doi: 10.1016/j.apenergy.2015.08.046

Croezen, H., Nusselder, S., Lindgreen, E. R., and Jaspers, D. (2018). Screening LCA for CCU Routes Connected to CO2 Smart Grid. Delft: CE Delft.

Cuéllar-Franca, R., García-Gutiérrez, P., Dimitriou, I., Elder, R. H., Allen, R. W. K., and Azapagic, A. (2019). Utilising carbon dioxide for transport fuels: the economic and environmental sustainability of different Fischer-Tropsch process designs. Appl. Energy 253:113560. doi: 10.1016/j.apenergy.2019.113560

Cuéllar-Franca, R. M., and Azapagic, A. (2015). Carbon capture, storage and utilisation technologies: a critical analysis and comparison of their life cycle environmental impacts. J. CO2 Util. 9, 82-102. doi: 10.1016/j.jcou.2014.12.001

de Best-Waldhober, M., Daamen, D., and Faaij, A. (2009). Informed and uninformed public opinions on $\mathrm{CO} 2$ capture and storage technologies in the Netherlands. Int. J. Greenhouse Gas Control 3, 322-332. doi: 10.1016/j.ijggc. 2008.09.001

de Best-Waldhober, M., Daamen, D. D. L., Ramirez, A. R., Faaij, A., Hendriks, C., and De Visser, E. (2012). Informed public opinion in the Netherlands: evaluation of $\mathrm{CO} 2$ capture and storage technologies in comparison with other CO2 mitigation options. Int. J. Greenhouse Gas Control 10, 169-180. doi: 10. 1016/j.ijggc.2012.05.023

de Visser, E., Hendriks, C., Barrio, M., Mølnvik, M. J., de Koeijer, G., Liljemark, S., et al. (2008). Dynamis CO2 quality recommendations. Int. J. Greenhouse Gas Control 2, 478-484. doi: 10.1016/j.ijggc.2008.04.006

DECARBit (2007). Enabling Advanced Pre-Combustion Capture Techniques and Plants. Oslo: EU-FP7.

Decision No 406/2009/EC (2009). Decision No 406/2009/EC of The European Parliament and of The Council. Brussels: European Union.

Dimitriou, I., García-Gutiérrez, P., Elder, R. H., Cuéllar-Franca, R. M., Azapagic, A., and Allen, R. W. K. (2015). Carbon dioxide utilisation for production of transport fuels: process and economic analysis. Energy Environ. Sci. 8, 1775-1789. doi: 10.1039/c4ee04117h

Directive 2004/35/CE (2004). Directive 2004/35/CE of the European Parliament and of the Council. Brussels: European Union.

Directive 2009/29/EC (2009). Directive 2009/29/EC of The European Parliament and of The Council. Brussels: European Union.

Dütschke, E., Wohlfarth, K., Höller, S., Viebahn, P., Schumann, D., and Pietzner, K. (2016). Differences in the public perception of CCS in Germany depending on CO 2 source, transport option and storage location. Int. J. Greenhouse Gas Control 53, 149-159. doi: 10.1016/j.ijggc.2016.07.043

Ecofys (2017). Prefeasibility Study CO2 Smart Grid. Utrecht: Ecofys.

Equinor (2020). What We Do. Stavanger: Equinor.

Federico, d. A., Lovisotto, L., and Bezzo, F. (2020). Introducing social acceptance into the design of CCS supply chains: a case study at a European level. J. Clean. Prod. 249:119337. doi: https://doi.org/10.1016/j.jclepro.2019.119337

Feenstra, C. F. J., Mikunda, T., and Brunsting, S. (2010). What Happened in Barendrecht?. Amsterdam: ECN.

Fischedick, M., Pietzner, K., Supersberger, N., Esken, A., Kuckshinrichs, W., Zapp, P., et al. (2009). Stakeholder acceptance of carbon capture and storage in Germany. Energy Proc. 1, 4783-4787. doi: 10.1016/j.egypro.2009.02. 304

Fortunato, E. (2018). Novel Carbon Capture and Utilisation Technologies (CCU): Research and Climate Aspects. Brussels: European Commission.

Gardarsdottir, S. O., De Lena, E., Romano, M., Roussanaly, S., Voldsund, M., Pérez-Calvo, J.-F., et al. (2019). Comparison of technologies for CO2 capture from cement production-part 2: cost analysis. Energies 12:542. doi: 10.3390/ en 12030542

Gasunie, and EBN (2018). Transport en Opslag van co2 in Nederland - Verkennende Studie Door Gasunie en EBN in Opdracht van het Ministerie van Economische Zaken. Groningen: Gasunie.
Gerlagh, R., Heijmans, R. J. R. K., and Rosendahl, K. E. (2020). COVID-19 tests the market stability reserve. Environ. Res. Econ. 76, 855-865. doi: 10.1007/s10640020-00441-0

Global CCS Institute (2019). Global Status of CCS 2019. Melbourne: Global CCS Institute.

Gough, C., Cunningham, R., and Mander, S. (2018). Understanding key elements in establishing a social license for CCS: an empirical approach. Int. J. Greenhouse Gas Control 68, 16-25. doi: 10.1016/j.ijggc.2017.11.003

Gross, C. (2007). Community perspectives of wind energy in Australia: the application of a justice and community fairness framework to increase social acceptance. Energy Policy 35, 2727-2736. doi: 10.1016/j.enpol.2006.12.013

Haan-Kamminga, A., Roggenkamp, M. M., and Woerdman, E. (2010). Legal uncertainties of carbon capture and storage in the EU: the Netherlands as an example. Carbon Clim. Law Rev. 4, 240-249. doi: 10.21552/cclr/2010/3/140

Hellemans, A. (2018). The Netherlands' carbon dilemma: sequester or recycle?[News]. IEEE Spectrum $55,7-9$.

Heydari, S., Ovenden, N., and Siddiqui, A. (2010). Real options analysis of investment in carbon capture and sequestration technology. Comput. Manag. Sci. 9, 109-138. doi: 10.1007/s10287-010-0124-5

Huijts, N. M. A., Molin, E. J. E., and Steg, L. (2012). Psychological factors influencing sustainable energy technology acceptance: a review-based comprehensive framework. Renew. Sustain. Energy Rev. 16, 525-531. doi: 10. 1016/j.rser.2011.08.018

IEAGHG (2016). Operational Flexibility of CO2 Transport and Storage, 2016/04, March 2016. Available online at: https://ieaghg.org/docs/General_ Docs/Reports/2016-04.pdf (accessed April 22, 2021).

IOGP (2019). The Potential for CCS and CCU in Europe. Madrid: International Association of Oil \& Gas Producers.

IOGP (2020). CCUS Projects in Europe. London: International Association of Oil $\&$ Gas Producers.

IPCC (2005). IPCC Special Report on Carbon Dioxide Capture and Storage. New York, NY: Intergovernmental Panel on Climate Change.

IPCC (2018). Global Warming of $1.5^{\circ} \mathrm{C}$. Geneva: Intergovernmental Panel on Climate Change.

Irlam, L. (2017). Global Costs of Carbon Capture and Storage. Melbourne: Global CCS Institute.

Jones, C. R., Olfe-Kräutlein, B., Naims, H., and Armstrong, K. (2017). The social acceptance of carbon dioxide utilisation: a review and research agenda. Front. Energy Res. 5:11. doi: 10.3389/fenrg.2017.00011

Karimi, F. (2017). Timescapes of CCS projects: is deferring projects and policies just kicking the can down the road? Energy Proc. 114, 7317-7325. doi: 10.1016/ j.egypro.2017.03.1862

Klimaatakkoord (2019). Klimaatakkoord. Den Haag: Rijksoverheid.

Klimaatwet (2019). Klimaatwet. Den Haag: Rijksoverheid.

Knoope, M. M. J., Ramírez, A., and Faaij, A. P. C. (2015). The influence of uncertainty in the development of a $\mathrm{CO} 2$ infrastructure network. Appl. Energy 158, 332-347. doi: 10.1016/j.apenergy.2015.08.024

Kraan, O., Kramer, G. J., Haigh, M., and Laurens, C. (2019). An energy transition that relies only on technology leads to a bet on solar fuels. Joule 3, 2286-2290. doi: 10.1016/j.joule.2019.07.029

Kraeusel, J., and Möst, D. (2012). Carbon capture and storage on its way to largescale deployment: social acceptance and willingness to pay in Germany. Energy Policy 49, 642-651. doi: 10.1016/j.enpol.2012.07.006

Kranenburg, K. V., Delft, Y. V., Gavrilova, A., Kler, R. D., Schipper, C., Smokers, R., et al. (2020). E-fuels: Towards a More Sustainable Future for Truck Transport, Shipping and Aviation. Rotterdam: SmartPort.

Krebbekx, J. A., de Wolf, W. J., Postma, B., Duivenvoorde, G. P. J., Lenselink, J., Meuzelaar, D. J., et al. (2012). De Sleutelrol Waarmaken. Leidschendam: VNCI.

Kuijper, M. (2011). Public acceptance challenges for onshore CO2 storage in Barendrecht. Energy Proc. 4, 6226-6233. doi: 10.1016/j.egypro.2011.02.635

Kuramochi, T., Ramírez, A., Turkenburg, W., and Faaij, A. (2012). Comparative assessment of $\mathrm{CO} 2$ capture technologies for carbon-intensive industrial processes. Prog. Energy Combust. Sci. 38, 87-112. doi: 10.1016/j.pecs.2011.05. 001

Leung, D. Y. C., Caramanna, G., and Maroto-Valer, M. M. (2014). An overview of current status of carbon dioxide capture and storage technologies. Renew. Sustain. Energy Rev. 39, 426-443. doi: 10.1016/j.rser.2014.07.093 
Lipponen, J., McCulloch, S., Keeling, S., Stanley, T., Berghout, N., and Berly, T. (2017). The politics of large-scale CCS deployment. Energy Proc. 114, 75817595. doi: 10.1016/j.egypro.2017.03.1890

Lockwood, T. (2017). Public Outreach Approaches for Carbon Capture and Storage Projects. London: IEA Clean Coal Centre.

Malins, C. (2017). What Role is There for Electrofuel Technologies in European Transport's Low Carbon Future?. London: Cerulogy.

Midden, C. J., and Huijts, N. M. (2009). The role of trust in the affective evaluation of novel risks: the case of CO2 storage. Risk Anal. 29, 743-751. doi: 10.1111/j. 1539-6924.2009.01201.x

Miller, E., Bell, L. M., and Buys, L. (2007). Public understanding of carbon sequestration in Australia: socio-demographic predictors of knowledge, engagement and trust. Int. J. Emerg. Technol. Soc. 5, 15-33.

Miller, E., Summerville, J., Buys, L., and Bell, L. (2008). Initial public perceptions of carbon geosequestration: implications for engagement and environmental risk communication strategies. Int. J. Glob. Environ. Issues 8, 147-164. doi: 10.1504/ijgenvi.2008.017265

Morfeldt, J., Nijs, W., and Silveira, S. (2015). The impact of climate targets on future steel production - an analysis based on a global energy system model. J Clean Prod 103, 469-482. doi: 10.1016/j.jclepro.2014.04.045

NLOG (2017). Projects. Available online at: https://www.nlog.nl/en/projects (accessed March 10, 2020)

Olajire, A. A. (2010). CO2 capture and separation technologies for end-of-pipe applications - a review. Energy 35, 2610-2628. doi: 10.1016/j.energy.2010.02. 030

PBL (2019a). Effecten Ontwerp Klimaatakkoord. Den Haag: PBL Netherlands Environmental Assessment Agency.

PBL (2019b). Klimaat- en Energieverkenning 2019. Den Haag: PBL Netherlands Environmental Assessment Agency.

Pérez-Fortes, M., and Tzimas, E. (2016). Techno-Economic and Environmental Evaluation of $\mathrm{CO} 2$ Utilisation for Fuel Production. Petten: European Commission Joint Research Centre.

Port of Rotterdam (2017). ROAD Project to be Cancelled, CCS to Continue. Available online at: https://www.portofrotterdam.com/en/news-and-pressreleases/road-project-to-be- cancelled-ccs-to-continue (accessed March 10, 2020)

Porteron, S., de Bruijne, E., le Den, X., Zotz, F., Olfe-Kräutlein, B., Marxen, A., et al. (2019). Identification and Analysis of Promising Carbon Capture and Utilisation Technologies, Including Their Regulatory Aspects. Brussels: European Commission.

Read, A., Gittins, C., Uilenreef, J., Jonker, T., Neele, F., Belfroid, S., et al. (2019). Lessons from the ROAD project for future deployment of CCS. Int. J. Greenhouse Gas Control 91, 102834. doi: 10.1016/j.ijggc.2019.102834

Regulation (EU) 2018/842 (2018). Regulation (EU) 2018/842of the European Parliament and of the Council of 30 May 2018 on Binding Annual Greenhouse Gas Emission Reductions by Member States from 2021 to 2030 Contributing to Climate Action to Meet Commitments under the Paris Agreement and Amending Regulation (EU) No 525/2013. Brussels: EU.

RIVM (2020). Greenhouse Gas Emissions in the Netherlands 1990-2018: National Inventory Report 2020. Bilthoven: National Institute for Public Health and the Environment.

Rotterdam CCUS (2019). Porthos a Step Closer: Four Companies Prepare CO2 Capture. Available online at: https://www.rotterdamccus.nl/en/porthos-a-stepcloser-four- companies-prepare-co\%E2\%82\%82-capture/ (accessed March 10, 2020)

Roussanaly, S. (2019). Calculating CO2 avoidance costs of carbon capture and storage from industry. Carbon Manag. 10, 105-112. doi: 10.1080/17583004. 2018.1553435

Rutten, H. (2020). Mapping Carbon of the Dutch Industry Today and How this can Evolve Towards Circularity. Ph. D. Thesis. Utrecht: Utrecht University.

SCP (2020). Op Weg Naar Aardgasvrij Wonen. De Energietransitie Vanuit Burgerperspectief. Den Haag: SCP.

Searle, S., and Christensen, A. (2018). Decarbonization Potential of Electrofuels in the European Union. Washington, DC: International Council on Clean Transportation.

Selma, L., Seigo, O., Dohle, S., and Siegrist, M. (2014). Public perception of carbon capture and storage (CCS): a review. Renew. Sustain. Energy Rev. 38, 848-863. doi: 10.1016/j.rser.2014.07.017
Shackley, S., Reiner, D., Upham, P., de Coninck, H., Sigurthorsson, G., and Anderson, J. (2009). The acceptability of CO2 capture and storage (CCS) in Europe: an assessment of the key determining factors. Int. J. Greenhouse Gas Control 3, 344-356. doi: 10.1016/j.ijggc.2008.09.004

Slagter, M. W., and Wellenstein, E. (2011). Drivers and barriers towards large scale Carbon Capture and Storage (CCS) deployment and possible government responses. Current insights from the Dutch perspective. Energy Proc. 4, 57385743. doi: 10.1016/j.egypro.2011.02.569

Söderholm, P., Bergquist, A.-K., and Söderholm, K. (2019). Environmental regulation in the pulp and paper industry: impacts and challenges. Curr. Forestry Rep. 5, 185-198. doi: 10.1007/s40725-019-00097-0

Stork, M., de Beer, J., Lintmeijer, N., and den Ouden, B. (2018). Chemistry for Climate: Acting on the Need for Speed. Leidschendam: VNCI.

Swennenhuis, F., Mabon, L., Flach, T. A., and De Coninck, H. (2020). What role for CCS in delivering just transitions? An evaluation in the North Sea region. Int. J. Greenhouse Gas Control 94:102903. doi: 10.1016/j.ijggc.2019. 102903

ter Mors, E., Weenig, M. W. H., Ellemers, N., Daamen, D. D. L., and de Best-Waldhober, M. (2009). Public information: on why and when multiple information sources are more effective than single information sources in communication about CCS. Energy Proc. 1, 4715-4718. doi: 10.1016/j.egypro. 2009.02.295

Terwel, B. W., and Daamen, D. D. L. (2012). Initial public reactions to carbon capture and storage (CCS): differentiating general and local views. Clim. Policy 12, 288-300. doi: 10.1080/14693062.2011.637819

Terwel, B. W., Harinck, F., Ellemers, N., and Daamen, D. D. L. (2010). Voice in political decision-making: the effect of group voice on perceived trustworthiness of decision makers and subsequent acceptance of decisions. J. Exp. Psychol. Appl. 16, 173-186. doi: 10.1037/a0019977

Terwel, B. W., Harinck, F., Ellemers, N., and Daamen, D. D. L. (2011). Going beyond the properties of CO2 capture and storage (CCS) technology: how trust in stakeholders affects public acceptance of CCS. Int. J. Greenhouse Gas Control 5, 181-188. doi: 10.1016/j.ijggc.2010.10.001

Toikka, A., Kojo, M., and Kainiemi, L. (2014). What is the socio-political scaffolding CCS needs to thrive? Case study from Finland. Energy Proc. 63, 7119-7124. doi: 10.1016/j.egypro.2014.11.747

Tvinnereim, E., and Mehling, M. (2018). Carbon pricing and deep decarbonisation. Energy Policy 121, 185-189. doi: 10.1016/j.enpol.2018.06.020

UNFCCC (2015). Adoption of the Paris Agreement. Bonn: United Nations.

Upham, P., and Roberts, T. (2011). Public perceptions of CCS: emergent themes in pan-European focus groups and implications for communications. Int. J. Greenhouse Gas Control 5, 1359-1367. doi: 10.1016/j.ijggc.2011.06. 005

van Alphen, K., van Voorst tot Voorst, Q., Hekkert, M. P., and Smits, R. E. H. M. (2007). Societal acceptance of carbon capture and storage technologies. Energy Policy 35, 4368-4380. doi: 10.1016/j.enpol.2007.03.006

van Bracht, M., and Braun, J. (2018). Eindrapportage: Joint Fact Finding: CO2Afvang en - Opslag. Paris: Klimaatakkoord.

van Egmond, S., and Hekkert, M. P. (2015). Analysis of a prominent carbon storage project failure - the role of the national government as initiator and decision maker in the Barendrecht case. Int. J. Greenhouse Gas Control 34, 1-11. doi: 10.1016/j.ijggc.2014.12.014

van Os, H. W. A., Herber, R., and Scholtens, B. (2014). Not under our back yards? A case study of social acceptance of the Northern Netherlands CCS initiative. Renew. Sustain. Energy Rev. 30, 923-942. doi: 10.1016/j.rser.2013.11.037

Verbruggen, A., Laes, E., and Woerdman, E. (2019). Anatomy of emissions trading systems: what is the EU ETS? Environ. Sci. Policy 98, 11-19. doi: 10.1016/j. envsci.2019.05.001

von der Assen, N., Voll, P., Peters, M., and Bardow, A. (2014). Life cycle assessment of CO2 capture and utilization: a tutorial review. Chem. Soc. Rev. 43, 7982-7994. doi: $10.1039 / \mathrm{C} 3 \mathrm{CS} 60373 \mathrm{C}$

Vosbeek, M., and Warmenhoven, H. (2007). Making Large-Scale Carbon Capture and Storage CCS in the Netherlands Work. Utrecht: Ecofys.

Warmenhoven, H., Kuijper, M., Soest, J. P. V., Croezen, H., and Gilden, N. (2018). Routekaart CCS. Delft: CE Delft.

Wijnia, Y., and Croon, J. D. (2018). The Value of CO2. Available online at: https:// www.assetresolutions.nl/en/column/the-value-of-co2 (accessed December 21, 2020) 
WorleyParsons (2009). Strategic Analysis of the Global Status of Carbon Capture and Storage: Report 1: Status of Carbon Capture and Storage Projects Globally. Canberra: Global CCS Institute.

Xenias, D., and Whitmarsh, L. (2018). Carbon capture and storage (CCS) experts' attitudes to and experience with public engagement. Int. J. Greenhouse Gas Control 78, 103-116. doi: 10.1016/j.ijggc.2018.07. 030

Yao, X., Fan, Y., Xu, Y., Zhang, X., Zhu, L., and Feng, L. (2019). Is it worth to invest? -An evaluation of CTL-CCS project in China based on real options. Energy 182, 920-931. doi: 10.1016/j.energy.2019.06. 100
Conflict of Interest: The authors declare that the research was conducted in the absence of any commercial or financial relationships that could be construed as a potential conflict of interest.

Copyright $\odot 2021$ Akerboom, Waldmann, Mukherjee, Agaton, Sanders and Kramer. This is an open-access article distributed under the terms of the Creative Commons Attribution License (CC BY). The use, distribution or reproduction in other forums is permitted, provided the original author(s) and the copyright owner(s) are credited and that the original publication in this journal is cited, in accordance with accepted academic practice. No use, distribution or reproduction is permitted which does not comply with these terms. 